\title{
Efficient Water Use Technology for Chemically Free Vegetable Production Through Farmer-to-Farmer Learning Process (FFLP)*
}

\author{
Krailert Taweekl, Kanya Kamsiripiman, Charin Mangklang, Siwarak Siwarom \\ Chiang Mai University, Chiang Mai, Thailand
}

\begin{abstract}
The purposes of the research were: (1) to study and develop the small watering irrigation; (2) to study and develop organic matter applying for vegetable cultivation; and (3) to increase farmer's knowledge base and develop a farmer-to-farmer learning. Development of small irrigation system watering on vegetable plot was designed and developed. Observation has been used for the development process record. The questions and focus group had been used to collect data. Qualitative and quantitative data were analyzed. Research found that before joining the project, the group used water pump and one-inch diameter plastic tube. It took more time and labors, after research project implementing, watering system consumed less time and labor. They, moreover, had enough water for watering year around. The study also presented that farmers innovated two formulas of herbal repulsive extraction and three formulas of liquid organic fertilizer. Farmers gained knowledge based on famer-to-farmer learning process on chemically free vegetable and organic matter production, save and potential water use technology system, and local marketing system and group management. The group also had one chemically free vegetable cultivation learning unit that consisted of demonstration. The study result showed that they had good opportunity to work with each other and exchange knowledge and experiences, not only group members but also farmers from outside the communities.
\end{abstract}

Keywords: vegetable, technology, farmer group, learning process, organic

Thailand is situated in the heart of the Southeast Asian mainland, covering an area of 513,115 square kilometers and extending about 1,620 kilometers from the north to the south and 775 kilometers from the east to the west. Thailand borders the Lao People's Democratic Republic and the Union of Myanmar to the North, the Kingdom of Cambodia and the Gulf of Thailand to the East, and Malaysia to the South. Thailand is a warm and rather humid tropical country with monsoonal climate. Temperatures are high in March and April with

\footnotetext{
* Thanks for Graduated School of Chiang Mai University, Chiang Mai Province, Thailand that provided the financial assist for participating the 3rd International Conference on Poverty and Sustainable Development 2016.

Corresponding author: Krailert Taweekl, MASc, assistant professor, Education Faculty, Chiang Mai University, Chiang Mai, Thailand; research field: rural development.

Kanya Kamsiripiman, Ph.D., associate professor, Education Faculty, Chiang Mai University, Chiang Mai, Thailand; research field: vacation education.

Charin Mangklang, Ph.D., associate professor, Education Faculty, Chiang Mai University, Chiang Mai, Thailand; research fields: social study and civil education.

Siwarak Siwarom, Ph.D., associate professor, Education Faculty, Chiang Mai University, Chiang Mai, Thailand; research field: fundamental education.
} 
average temperature of 28 degree Celsius to 38 degree Celsius and humidity averaging between $73 \%$ and $82.8 \%$. The Northeast Thailand has been consistently the target area of this research. The agricultural land is as large as 9,271,520 hectares in Northeast region, which accounts for $44 \%$ of all in Thailand (21,014,620 hectares) and number of the farm household $(5,642,890$ hectares). The agriculture in this region is characterized by less favored or less developed due to the poor natural conditions such as sandy soil, erratic rainfall. The Northeast region, especially around Khon Kaen Province, is generally characterized by gently rolling topography with an elevation of approximately 200 meters. The research site, Don Han village located in 30 kilometers west from Khon Kaen City, is also in the same topography as mentioned above in terms of soil characteristic and rainfed area. The dominant farming system around Khon Kaen Province is the rice in paddy, vegetable, and sugarcane.

At the present and the future, Thailand has capacity to produce the chemically free and organic food for consumption and export. It can be seen that Thailand shares approximately $10 \%$ to world market. This result to the trend of world organic food market will increase $20 \%$ per year. This causes the awareness on health of customers (Department of Agriculture, 2000). Pumpanwong (2004) mentioned that the chemical can contaminate directly to the food in every process such as the production at farm, post-harvesting, transportation, and cooking step. The food production is the high chance to get toxic from using the chemical. The chemically free vegetable is very important for human being, thus, it is very important for farmers to produce as customers need. The quality control should be done in this step. Thus, at farm level, the farmer group can play a significant role in controlling and managing the production process.

Whole vegetable production of Thailand has been consumed in the country about $95 \%$, approximately 3.7 million tons per year, and it costs 18,600 million baht (Rojanasatian, 2003). Thai people consume vegetable 60 kilograms per year. The average vegetable cost for whole year is five baht per kilogram. Furthermore, 5\% of the vegetable is exported. In 2003, the report presented that Thailand exported the vegetable of 519,849 tons, it cost 7,938 million baht. The country also exported the vegetable seed which costs 1,433 million baht. Overall, the vegetable production in Thailand is divided into three groups: (1) fresh vegetable; (2) food processing; and (3) seed production. The main problems for farmer to produce the vegetable are the vegetable price, marketing channel, and using chemical for both fertilizer and pesticide. Another difficulty is inappropriate irrigation system that consumed more labors and energy costs. The purposes of the study were: (1) to study and develop the small watering technology for chemically free vegetable production; (2) to study and develop the organic matter for productions of chemically free vegetable; and (3) to increase farmer's knowledge base and develop a farmer-to-farmer learning unit in the community.

The problem of extension approach in Thailand is the lack of a close working relationship between researchers and extensionists. Instead, they try to increase the flow of resources coming to their respective institutions and to solve day-to-day management problems, rather than ensuring that their respective organizations contribute to the broader goal of getting improved agricultural technology transferring to farmers. The transition to diversified small farming systems will require new skills and capacities among farmers. Traditional forms of extension support to rural farmers from the Green Revolution era, such as the Training and Visit system (T\&V), addressed crop and livestock production through technological packages. The nature of knowledge needed today is more complex, diverse, and local. Much of this knowledge needs to be developed or adapted "on the spot" through local experimentation by farmers. Thus, FFLP (famer-to-farmer learning process) 
was developed for new agricultural extension since to solve the old extension method. Taweekul et al. (2015) found that FFLP provided benefits to adapt farmers in terms of gaining high income and reducing cost. Thus, this research, furthermore, had used FFLP approach to transfer knowledge among farmers.

\section{Methodologies}

Two research methodologies have been used for collecting data, they were as following:

(1) The interviews of 31 farmers who were the members of chemically free vegetable production group at Don Han village, Khon Kaen Province, Thailand, were done as shown in Figure 1. Then, the three focus groups were also used for deep discussion. The data have been analyzed by the number and explanation;

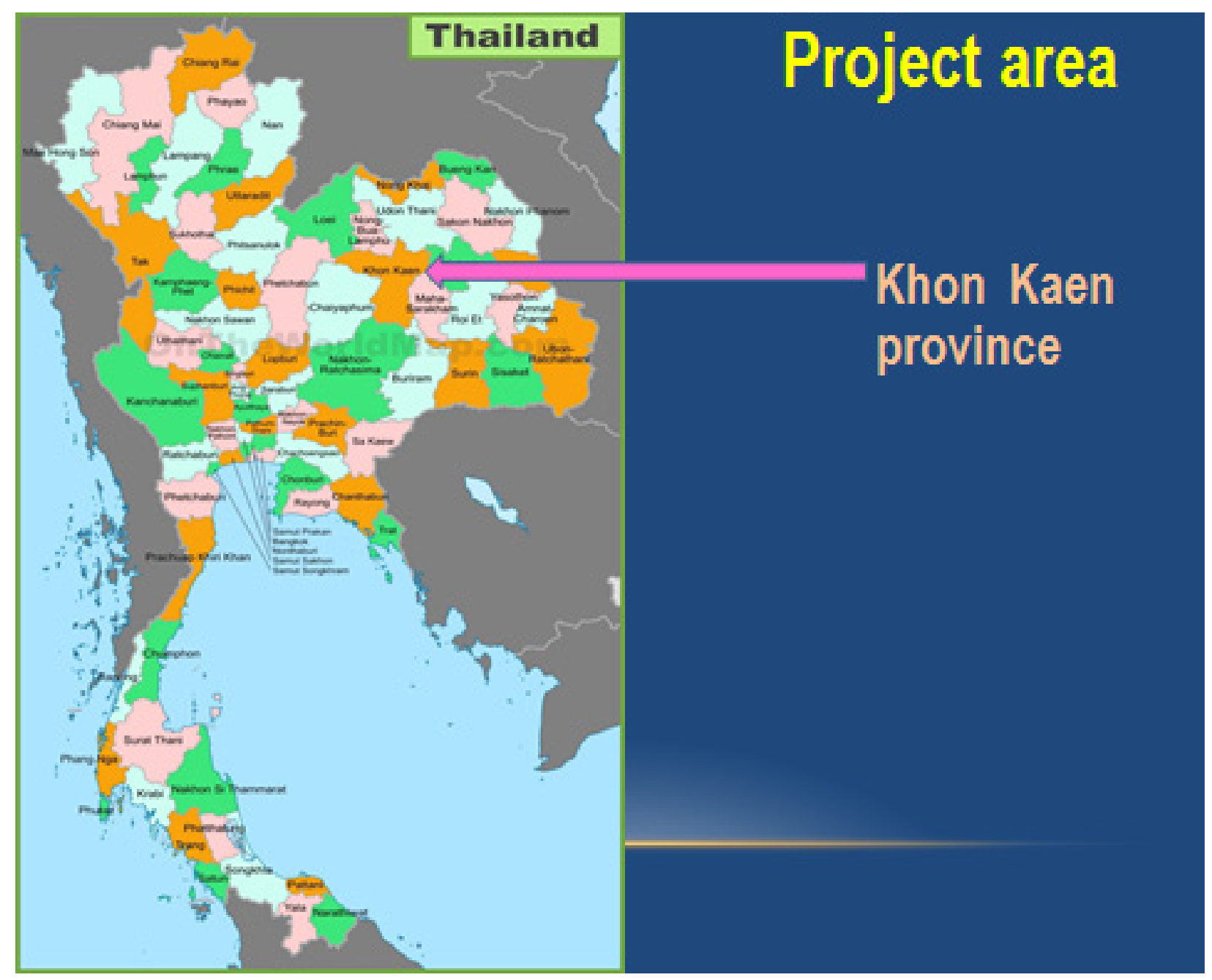

Figure 1. Project research area.

(2) The setting of small watering system to irrigate the chemically free vegetable production on farmer's farm about 0.55 hectares had been done. This plot of land also has been used for the learning unit of group members (see Figures 2 and 3). The farmer recorded data according to irrigation operating time, number of labor, investing cost, energy cost, etc. The data were used for comparing between the old irrigation technology system and the current irrigation technology system. The data were analyzed by the figure and the description. 


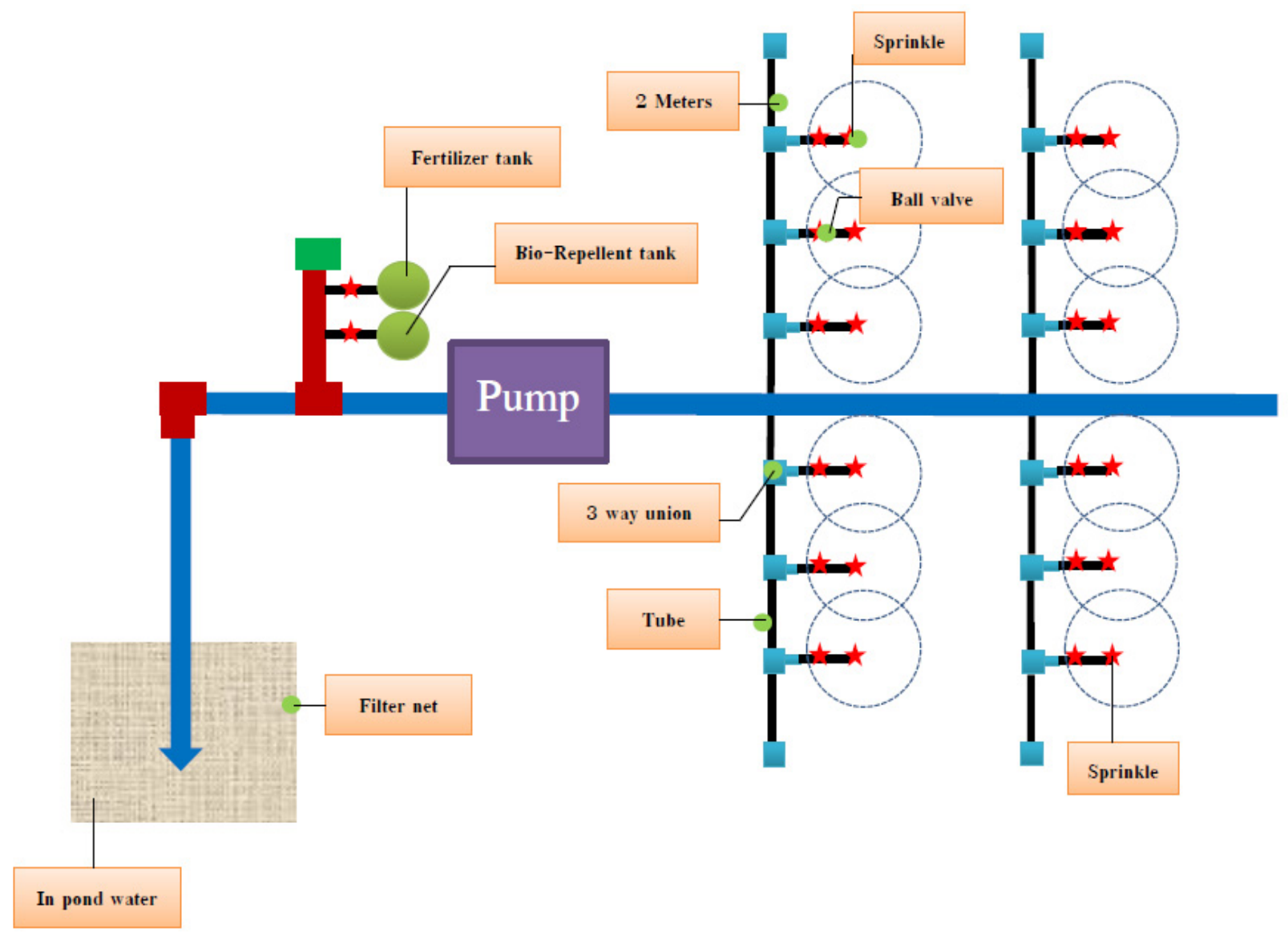

Figure 2. Irrigation system on blue print.

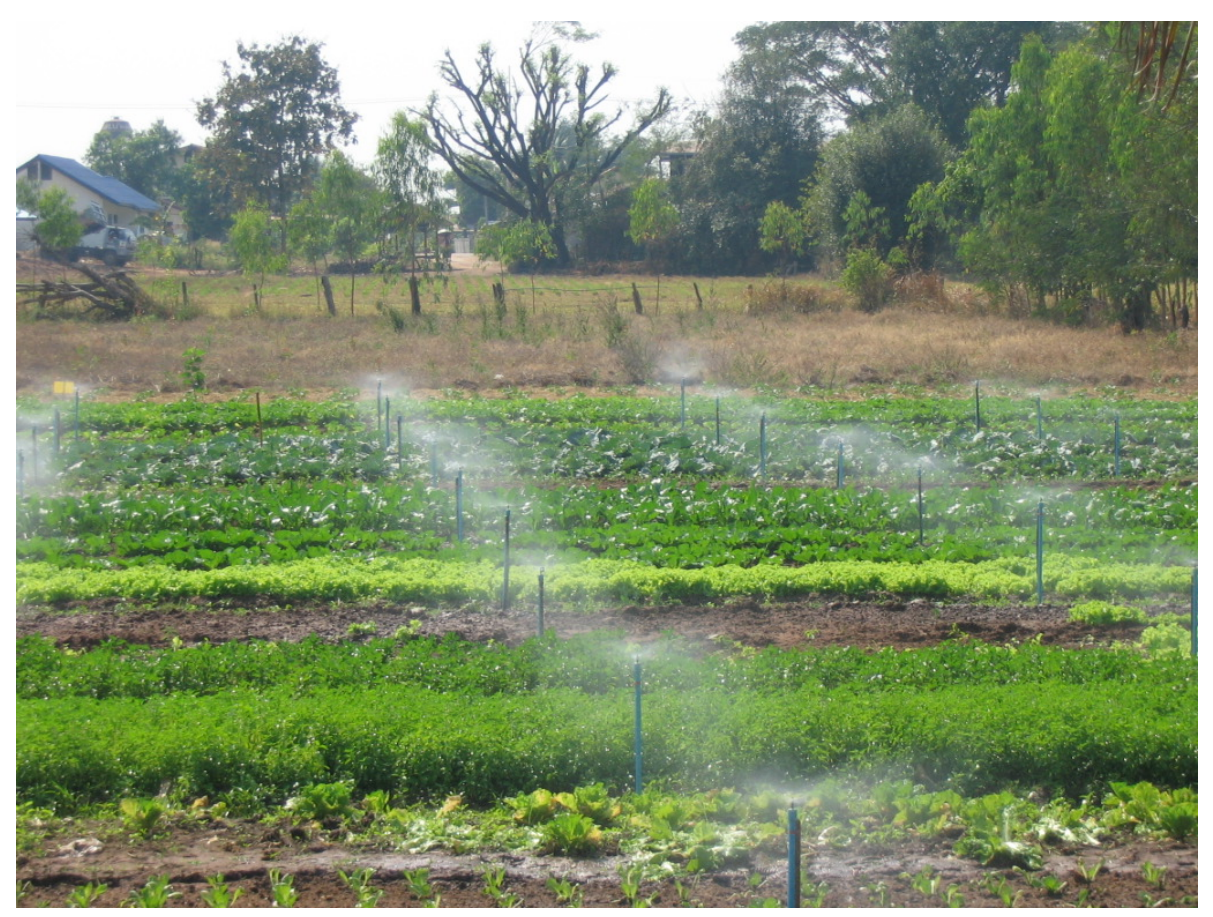

Figure 3. Irrigation system at demonstration plot. 


\section{Results and Discussion}

\section{Socio-economic Aspects of Chemically Free Vegetable Group Members}

The result found that the family size of farmer was 4.5 , each family consisted of father, mother, and either children or nephews. The average labor force per family was 2.5. The main labors are father, mother, including son-in-law and daughter-in-law, while other family members have worked in the big cities such as Bangkok and its outskirts, Phuket, and the factories located near the village. The average age of the member was 56.28 years old, the youngest member was 35 years old, while the oldest was 68 years old. The average land holding was 20.28 rai (6.25 rai is equally 1 hectare). Each member of chemically free vegetable production group was allocated 1.5 rai to generate the vegetable production by using the farm ponds and the natural canal near farms. Moreover, farmers also devoted 18 rai to grow the rice for consumption and selling. Importantly, the whole land belonged to them. The members started to produce organic rice after they learnt on organic matter. Various vegetables were grown such as Chinese kale, chili, egg plant, long bean, morning glory, cabbage, sweet corn, basil, etc.

The study revealed that the farmer group played an important role in implementing the chemically free vegetable production. The chemically free vegetable production group was founded on January 8,2002 . At the beginning, there were 12 members. Each member shared 20 baht. At present, the number of member has increased up to 35 farmers, and each farmer holds the share at 200 baht. One group member provided the land, 0.55 hectares, for the group activities as demonstration plot by growing vegetable, making the organic matter and meeting. The water sources were four farm ponds which were located near the demonstration plot and there was no renting fee for the group.

\section{The Development of Small Water Irrigation by Farmer Group}

The study found that the old irrigation technology system was very difficult to generate the system in terms of consuming of many labors, much time, and high energy cost. The research found that the group members used three horse power water pumps using the petrol connecting with plastic pipe diameter being one inch and the length was 100 meters which needed 5-6 farmers for watering three hours per day as shown in Table 1. After the group has used new irrigation technology system (small sprinkler), it took less labor and time, for instance, it needed 1-2 members to watering only 25 minutes per day. This was suitable for the group that consisted of elder members. Furthermore, the group connected the water irrigation system with the organic liquid fertilizer and herbal repulsive extraction tanks. Thus, this appropriate irrigation system resulted directly to save time, save budget, and use more often for applying liquid herbal organic matters. Moreover, the efficient water was done by using the irrigation system.

Table 1

Comparison of the Irrigation Technology Between Using Water Pump and Sprinkler Irrigation System

\begin{tabular}{|l|l|l|}
\hline Activities & Old irrigation system & New irrigation system \\
\hline 1. Labor for watering & 1. Five labors per day & 1. One-two labors per day \\
\hline 2. Water applying time & 2. Took three hours/day & 2. Took 25 minutes/day \\
\hline 3. Insect spraying applied & 3. One-two farmers/1 hour & 3. One farmer $/ 5$ minutes (mixed in the irrigation system) \\
\hline 4. Liquid organic fertilizer applied & 4. One-two farmers/1 hour & 4. One farmer $/ 5$ minutes (mixed in the irrigation system) \\
\hline 5. Energy cost & 5. Petrol costs 1,500 baht/month & 5. Electricity costs 150 baht/month \\
\hline 6. First investment & 6. Cost 10,600 baht & 6. Cost 34,000 baht \\
\hline 7. Water available & 7. For 8 months & 7. For 12 months \\
\hline
\end{tabular}




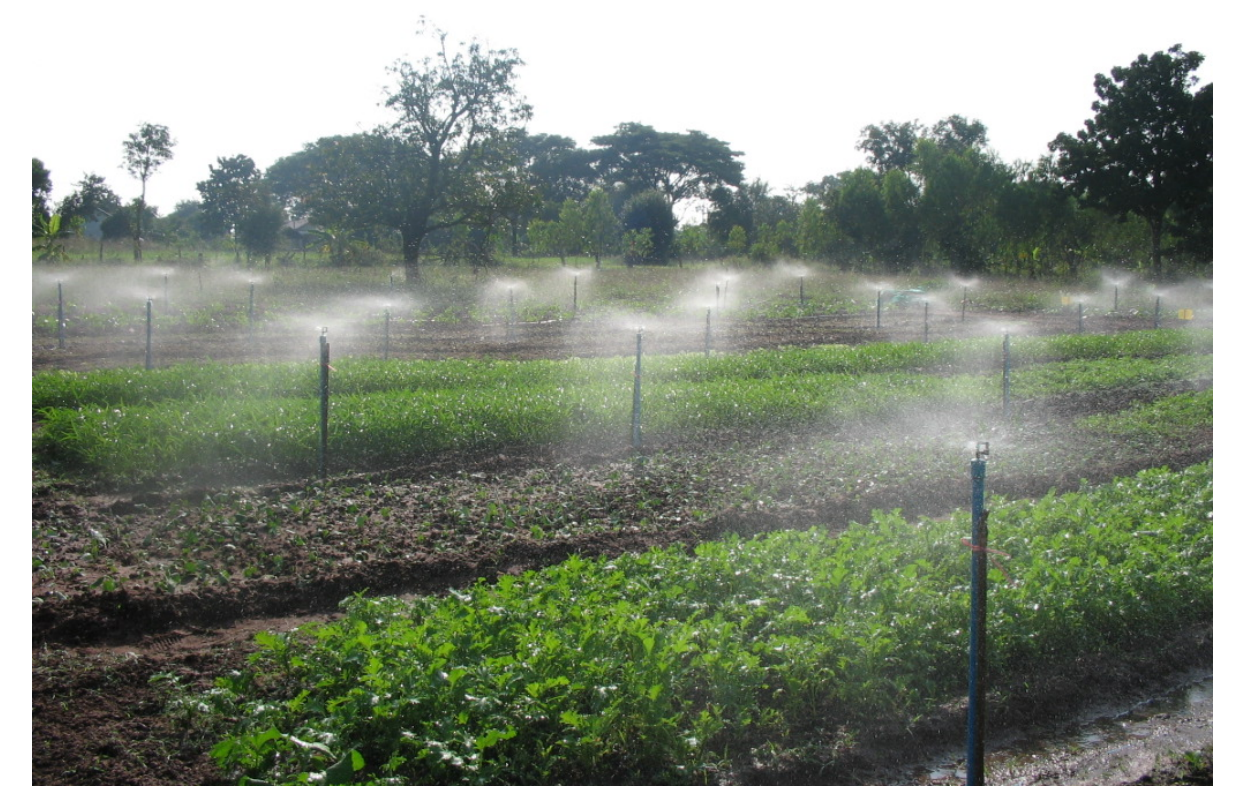

Figure 4. Sprinkle system.

Table 1 shows that the number of labor for watering, applying the liquid fertilizer and the bio-pesticide was decreased from using old technology to present technology, from five farmers to 1-2 farmers, respectively. The watering time also decreased sharply from three hours per day to 25 minutes per day. Interestingly, the energy cost of water pump paid by farmer group was cheaper than old system as seen from 1,500 baht per month to 150 baht per month. According to the investment, the old irrigation system was cheaper than new water system. The farmer also mentioned that growing vegetable by using the water sprinkler system, as shown in Figure 4, connected with the mixed fertilizer and herbal extraction, caused vegetable to grow vary fast, had less insect and disease, and quality of soil also had been improved. More importantly, farmer used water so efficiently that they could save water using whole year instead of eight months per year.

\section{Herbal and Organic Matter Development}

Herbal repulsive extraction development. The study found that farmers have produced the herbal extraction by fermented the herbs in the tank. The result mentioned that farmers developed the equipment for extraction, named "herbal repulsive extraction". It consists of two parts: (1) boiling tank; and (2) cooling tank. Both parts are connected by the copper tube. The operation system was putting the herbal plants into the boiling tank then boiled it. The stream passed through the copper tube to water cooling tank. Next, the stream changed to be liquid which is used for expelling the insects. Five kilograms of herbal plants by weight can be refined to five liters of bio-extraction. It took 2-3 hours. In addition, the operating time and quantity of the bio-extraction depended on the temperature of boiling and cooling tanks. The characteristics of the herbal bio-extraction are presented in Figure 5.

Farmer group investigated the types of herbal plants from eight plants to 12 plants to produce the bio-extraction. These plants (see Figure 6) can be found in the bush around the village. And also three popular formulas of bio-extraction have been shown in the Table 2 below. 


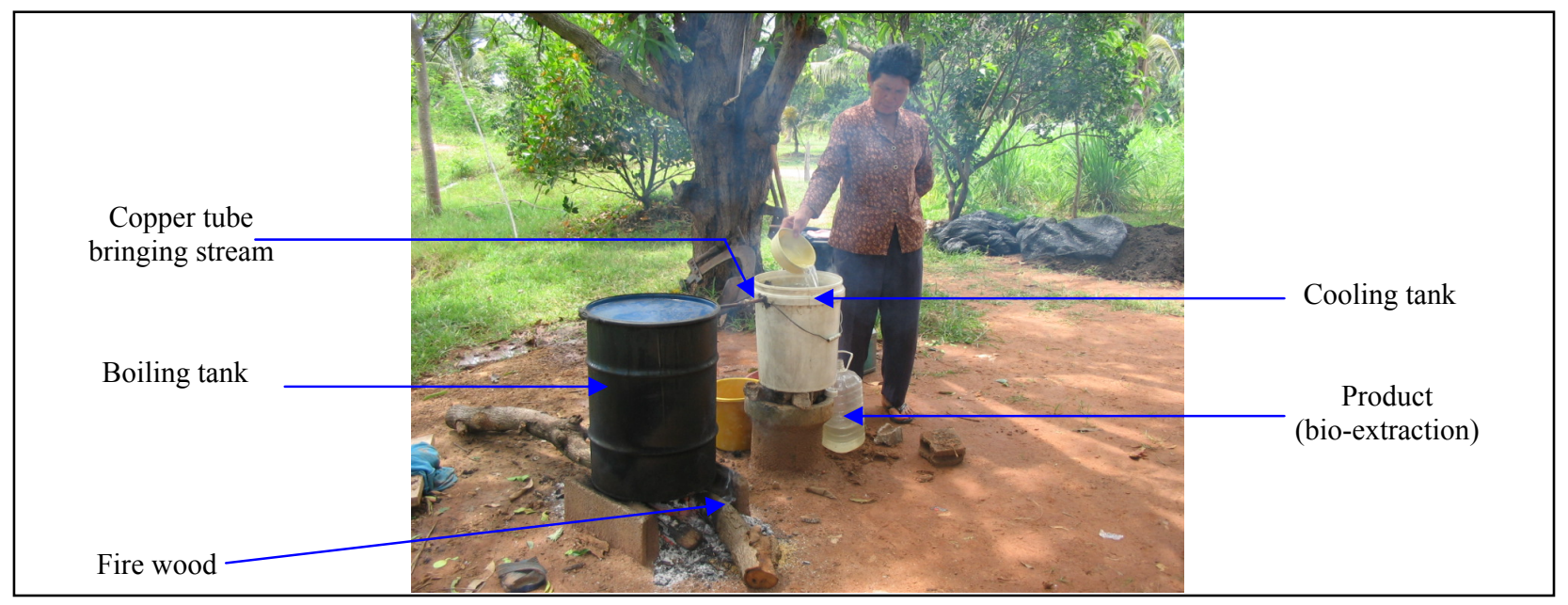

Figure 5. Herbal repulsive extraction equipment.

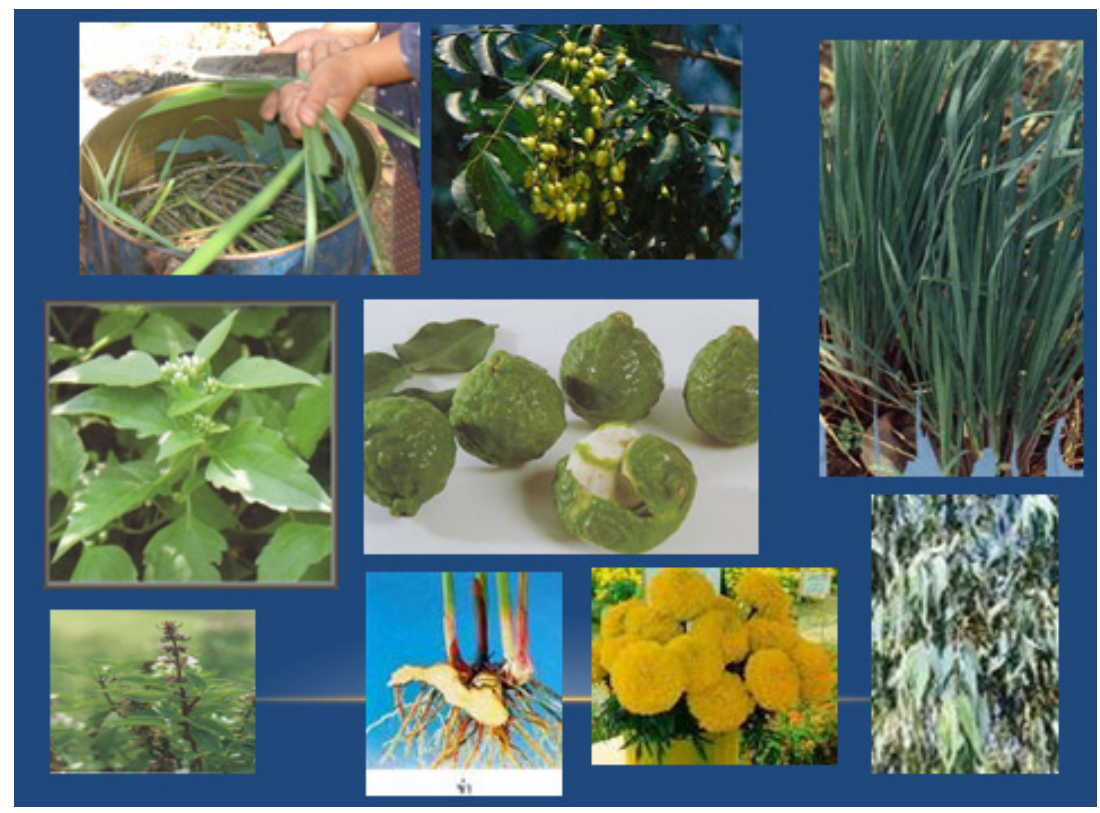

Figure 6. Herbal plants were used for extraction.

Table 2

Formulas and Types of Herbal Plants to Produce the Herbal Repulsive Extraction

\begin{tabular}{|c|c|c|c|c|c|}
\hline \multicolumn{2}{|c|}{ Formula 1 (to expel insect) } & \multicolumn{2}{|l|}{ Formula 2 (to expel insect) } & \multicolumn{2}{|c|}{ Formula 3 (to expel mosquito ) } \\
\hline Herbal plants & Used part & Herbal plants & Used part & Herbal plants & Used part \\
\hline $\begin{array}{l}\text { 1. Citronella } \\
\text { 2. Neem } \\
\text { 3. Eucalyptus } \\
\text { 4. Kaffir lime } \\
\text { 5. Galangal } \\
\text { 6. Custard apple } \\
\text { 7. Siam weed } \\
\text { 8. Kassod tree }\end{array}$ & $\begin{array}{l}\text { Leaf } \\
\text { Leaf/seed } \\
\text { Leaf } \\
\text { Leaf/fruit } \\
\text { Tuber } \\
\text { Leaf } \\
\text { Leaf } \\
\text { Leaf }\end{array}$ & $\begin{array}{l}\text { 1. Citronella } \\
\text { 2. Neem } \\
\text { 3. Eucalyptus } \\
\text { 4. Kaffir lime } \\
\text { 5. Galangal } \\
\text { 6. Custard apple } \\
\text { 7.Siam weed } \\
\text { 8. Kassod tree } \\
\text { 9. Tuba root } \\
\text { 10. Tinospora crispa (L) } \\
\text { 11. Wild spikenard } \\
\text { 12. Stemona callinae }\end{array}$ & $\begin{array}{l}\text { Leaf } \\
\text { Leaf/seed } \\
\text { Leaf } \\
\text { Leaf/fruit } \\
\text { Tuber } \\
\text { Leaf } \\
\text { Leaf } \\
\text { Leaf } \\
\text { Stem/root } \\
\text { Stem } \\
\text { Leaf/tip } \\
\text { Tuber }\end{array}$ & $\begin{array}{l}\text { 1. Citronella } \\
\text { 2. Eucalyptus } \\
\text { 3. Kaffir lime }\end{array}$ & $\begin{array}{l}\text { Leaf } \\
\text { Leaf } \\
\text { Leaf/fruit }\end{array}$ \\
\hline
\end{tabular}


Presently, the farmer group still investigates the local herbal plants for producing bio-extraction. New plant Dioscorea hispida Dennst is demonstrated on farm to expel insects. This illustrated that farmer can do the research and teach other farmers, including work together to solve their similar problems.

\section{Liquid Organic Fertilizer Making}

The study revealed that farmer was used to attending the training course on organic matter making organized by the agricultural extension district office, other farmers, and Khon Kaen University. Then, the farmer group has developed the organic making method, formula, and the raw materials suitable to their agricultural activities focusing on rice farm and vegetable cultivation. The local materials have been considered to be used instead of buying from outside. For instance, jack fruit, star fruit, mango, and pumpkin were investigated. Three liquid organic fertilizer formulas are found as shown in Table 3 below.

Table 3

Three Formulas of Liquid Organic Fertilizer and Local Raw Materials

\begin{tabular}{|c|c|c|c|c|c|}
\hline \multicolumn{2}{|l|}{ Formula 1} & \multicolumn{2}{|l|}{ Formula 2} & \multicolumn{2}{|l|}{ Formula 3} \\
\hline Materials & Ratio & Materials & Ratio & Materials & Ratio \\
\hline $\begin{array}{l}\text { 1. Pineapple } \\
\text { 2. Sugarcane molasses } \\
\text { 3. Coconut juice } \\
\text { Total }\end{array}$ & $\begin{array}{l}3 \mathrm{kgs} \\
1 \mathrm{~kg} \\
1 \mathrm{~kg} \\
5 \mathrm{kgs}\end{array}$ & $\begin{array}{l}\text { 1. Star fruit, jack fruit, pumpkin, } \\
\text { mango, carrot, banana } \\
\text { 2. Sugarcane molasses } \\
\text { 3. Water } \\
\text { 4. Effective micro-organism } \\
\text { LDD powder number } 2 \\
\text { Total }\end{array}$ & $\begin{array}{l}3 \mathrm{kgs} \\
1 \mathrm{~kg} \\
1 \mathrm{~kg} \\
25 \mathrm{gm} \\
7.25 \mathrm{kgs}\end{array}$ & $\begin{array}{l}\text { 1. Waste vegetable from } \\
\text { farm } \\
\text { 2. Sugarcane molasses } \\
\text { 3. Water } \\
\text { 4.Cocobnut juice } \\
\text { 5. Effective micro-organism } \\
\text { LDD powder number } 2 \\
\text { Total }\end{array}$ & $\begin{array}{l}3 \mathrm{kgs} \\
1 \mathrm{~kg} \\
1 \mathrm{~kg} \\
3 \mathrm{kgs} \\
25 \mathrm{gm} \\
8.25 \mathrm{kgs}\end{array}$ \\
\hline \multicolumn{2}{|c|}{$\begin{array}{l}\text { Method: } \\
\text { Chop pineapple into small piece, and then } \\
\text { add sugarcane molasses and coconut juice. } \\
\text { Next, stirring it properly may need, cover } \\
\text { lid and stir every 2-3 days. Fermentation } \\
\text { needs } 30 \text { days. }\end{array}$} & \multicolumn{2}{|c|}{$\begin{array}{l}\text { Method: } \\
\text { Chop the local fruit into small piece, and then } \\
\text { add sugarcane molasses, water, and coconut } \\
\text { juice in the container. Also adding LDD no. } 2 \\
\text { in it is needed. Next, stirring it properly may } \\
\text { need, cover lid and stir every 2-3 days. } \\
\text { Fermentation needs } 30 \text { days. }\end{array}$} & \multicolumn{2}{|c|}{$\begin{array}{l}\text { Method: } \\
\text { Chop vegetable from farm into small } \\
\text { piece, and then add sugarcane } \\
\text { molasses, water, and coconut juice in } \\
\text { the container. Also adding LDD no. } 2 \\
\text { in it is needed. Next, stirring it } \\
\text { properly may need, cover lid and stir } \\
\text { every 2-3 days. Fermentation needs } 30 \\
\text { days. }\end{array}$} \\
\hline
\end{tabular}

Note. $\mathrm{LDD}=$ Land Development Department.

The study found that formulas 2 and 3 of liquid organic fertilizer were preferable for farmer. The reasons were: (1) various local raw materials were available; (2) LDD powder number 2 stimulating micro-organism was very active; and (3) farm products were properly and efficiently used.

\section{Increasing Farmer Knowledge Through FFLP}

Their knowledge and experience is very important for themselves and other farmers to modify in their farms. The efficient water use and organic matter for farms are main issues. The study investigated that farmer group has developed and improved the chemically free vegetable plot to be the demonstration and learning unit which other farmers come to learn from each other. The learning unit consisted of: (1) one learning hut, its area was 32 square meter; (2) liquid organic fertilizer demonstration; (3) herbal repulsive extraction demonstration; (4) cooperative chemically free vegetable demonstration plot; (5) herbal plant plot; (6) latrine for visitors; and (7) four water ponds for irrigation. It can be seen that the area of 0.55 hectares has been for various activities especially learning process and on farm trial which farmers have implemented to solve their problems. The learning unit is located near the village, resulting that many villagers can easily access this farm both for buying 
the vegetable and exchanging the experiences through FFLP as shown in Figure 7. Thus, this learning unit was almost suitable place to share knowledge from farmers on various issues of chemically vegetable production.

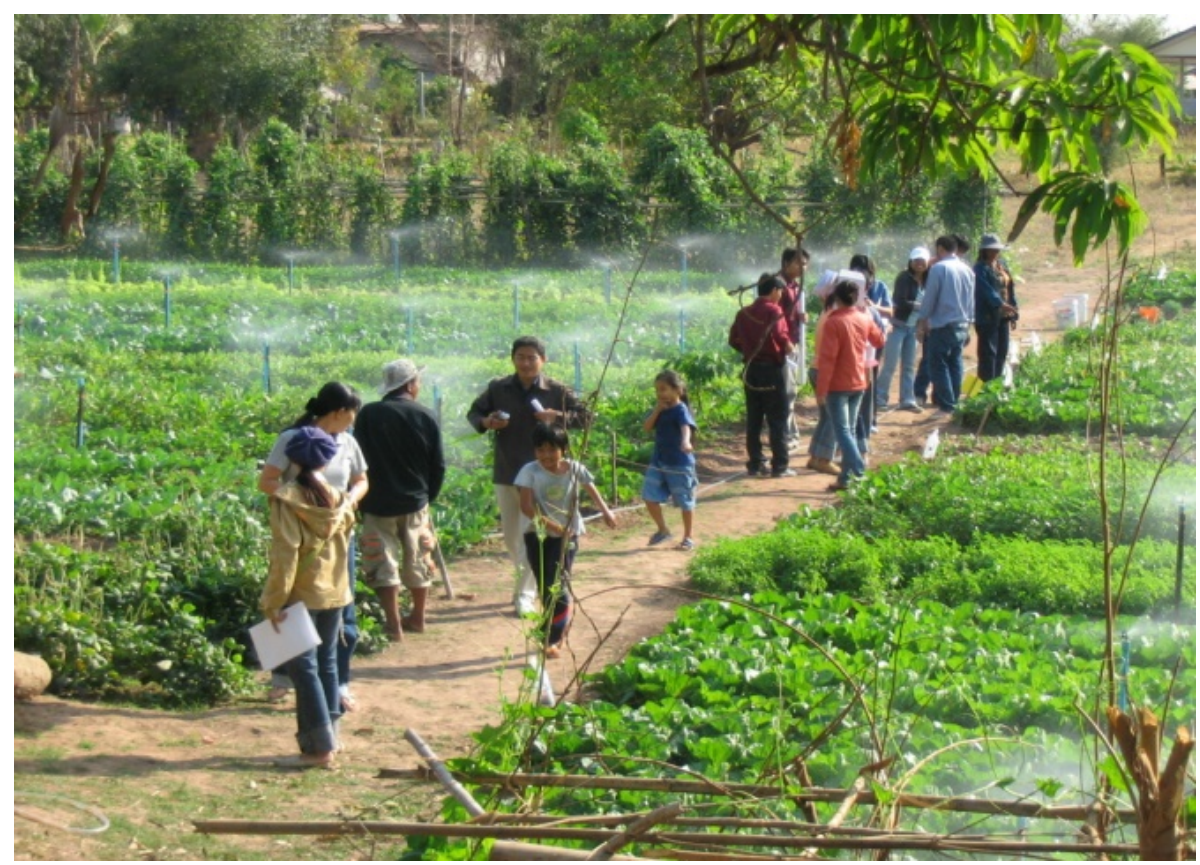

Figure 7. FFLP on demonstration plot.

The study also found that the group members have created and applied the agricultural activities suitable for the chemically free vegetable production. The members also practiced on testing the organic matter making, and vegetable cultivation including new varieties. These farm trials were operated to solve their problems and then modified to both cooperative demonstration plot and their own lands. The knowledge base of farmers happened from their experiences. The research results mentioned that many members were experts in various aspects, for instance, four members were keen on small water irrigation system by using sprinkler connected with fertilizer mixing tank; six members had the skill on liquid organic fertilizer making. Furthermore, three members operated the herbal repulsive extraction excellently; other two members were also keen on making the insect trap. The group learnt more on marketing system until five members had good skills; moreover, two farmers were the soil improvement volunteer supporting the group on soil test and finding out the solutions. In addition, three members had good skill and good practices on group management. Thus, their knowledge base has transferred to many people and students who visited the learning unit. It can be seen that 1,049 visitors from 36 groups, in each year both from Thailand and overseas have visited. So, it can be concluded that knowledge based on experience leads them to be confident to transfer to others. Importantly, the FFLP is very important extension method for farmers and outsiders to work and learn together.

\section{Conclusions and Recommendations}

(1) The farmer group has an important role in promoting and producing chemically free vegetable by stimulating the 30 members to learn from each other at the learning unit before implementing on their own farm. The learning unit includes chemically free vegetable demonstration plot, efficient water use technology, the learning hut for training and meeting, latrine, organic matter demonstration, and four farm ponds; 
(2) The farmer group has developed and improved the water irrigation system from using petrol motor pump with 100 meters of plastic pipe to use the sprinkler technology connecting with the liquid organic fertilizer mixed tank. The water pump was electricity submersible pump. This appropriate technology reduced labor for watering 3-5 times, reduced watering time about 4.8 times, reduced time for applying the fertilizer and bio-extraction 12 times, and reduced the cost for energy paying 12 times;

(3) The farmer group created and improved the herbal repulsive extraction, two formulas and mosquito expelling, one formula. In addition, they have developed three formulas of liquid organic fertilizer using local raw materials. The equipment can use multiple energy sources suitable for each area such as natural gas, fire wood, and charcoal;

(4) The group members have learnt on many topics from the group. They also gained experiences from implementing the research on farms. The trial has been done to solve their problems. Actually, the knowledge becomes local knowledge base which the group can transfer to other farmers including people who are interested in these issues. Their knowledge base has led the group moving forward and keeping walking properly. Furthermore, it also provided the opportunity for the group members to participate in various seminar and meeting;

(5) Farmers have learnt the technologies and methods how to modify farm practice during the climate change, especially when they have succeeded in using the appropriate technologies of efficient water use and various organic matters instead of chemical;

(6) Farmer should investigate other energy sources to pump water such as solar cell, wind, and others.

\section{References}

Caldwell, J. S., Sukchan, U., Sukchan, S., Suphanchaimat, N., Ando, M., Oda, M., ... Phaowphaisal, I. (2006). A framework for farmer participatory technology research. In O. Ito and Kokusai Nōrin Suisangyō Kenkyū Sentā (Eds.), Increasing economic option rainfed agriculture in Indochina through efficient use of water resource (pp. 109-114). JIRCAS Working Report. Tsukuba, Japan: JIRCAS.

Chophunit, S. (2003). Plant hormone and nutrient in bio-liquid organic fertilizer. Bangkok: Agricultural Co-operative Publication.

Department of Agriculture. (2000). Standard of organic crop production in Thailand. Bangkok: Agricultural Co-operative Publication.

Liangjamroon, W. (1998). Optional agriculture: The self-reliance of Thai society. Network of optional agriculture. Bangkok, Thailand.

Phanthupanij, S. (2001). Agricultural extension (p. 579). Bangkok, Thailand: Ruamsarn 1997 Publishing Company.

Pumpanwong, R. (2004). Organic home garden. Bangkok: Prasarnmitr Publication.

Rojanasatian, B. (2003). Boonchu pointed the direction of Thai agriculture to kitchen of the world. Bangkok, Thailand: Bancheun Publication.

Sinja, J., Karugia, J., Waithaka, M., Miano, D., Baltenweck, I., Franzel, S., Nyikal, R., \& Romney, D. (2004). Adoption of fodder legumes technology through farmer-to-farmer extension approach. Uganda Journal of Agricultural Sciences, 9, 222-226.

Suksawat, M. (2005). Organic fertilizer. Bangkok, Thailand: Home and Garden Publication.

Taweekul, K., Caldwell, J., Yamada, R., \& Fujimoto, A. (2009). Assessment of the impact of a farmer-to-farmer learning and innovation scaling out process on technology adaptation, farm income and diversification in Northeast Thailand. International Journal of Technology Management and Sustainable Development, 8(2), 129-144.

Taweekul, K., Kamsiripiman, K., Mangkhang, C., Maneekul, J., \& Siwarom, S. (2015). Dissemination a model of farmer-to-farmer learning process (FFLP) and its technologies to local administration organization for improving the agricultural extension service. Advanced Science Letters, 21(2), 162-164. 